Ilmu Dakwah: Academic Journal for Homiletic Studies Volume 11 Nomor 1 (2017) 151-176 DOI: 10.15575 /idajhs.v11i1.1356

http://journal.uinsgd.ac.id/index.php/idajhs ISSN 1693-0843 (Print) ISSN 2548-8708 (Online)

\title{
Strategi Komunikasi Badan Amil Zakat Nasional dalam Pengumpulan Zakat Maal
}

\author{
Rama Wijaya Kesuma Wardani ${ }^{a}$ \\ UIN Sunan Gunung Djati, Bandung \\ "aldiscooter7@gmail.com
}

\begin{abstract}
This study aims to find out: communication strategy of National Amil Zakat Agency (Baznas) covering communication management, communication form, and socialization in collecting Zakat Maal. Research in Baznas West Java Province is done using qualitative approach with descriptive method whose data obtained through observation, interview, and documentation. The results of the study found that communication strategy used by Baznas of West Java Province in collecting zalcat maal was done through the implementation of International Standard Operation (ISO) and Strategic Plan (RESTRA) and Initial Activity Plan (RKAT). The form of communication in collecting zakat maal using online media means and face to face communication, with muzakki. While socialization of zalcat gathering maal done continuously through work program branding mechanism of online media and offline. Through this communication strategy Baznas West Java Province managed to increase the amount of zakat gathering maal from the community.
\end{abstract}

Keywords: Communication Strategy, Socialization; Zakat Maal; National Amil Zakat Board

\begin{abstract}
ABSTRAK
Penelitian ini bertujuan untuk mengetahui: strategi komunikasi Badan Amil Zakat Nasional (Baznas) meliputi manajemen komunikasi, bentuk komunikasi, dan sosialisasi dalam pengumpulan Zakat Maal. Penelitian di Baznas Provinsi Jawa Barat ini dilakukan menggunakan pendekatan kualitatif dengan metode deskriptif yang datanya diperoleh melalui observasi, wawancara, dan dokumentasi. Hasil penelitian menemukan bahwa strategi komunikasi yang digunakan oleh Baznas Provinsi Jawa Barat dalam mengumpulkan zakat maal dilakukan melalui penerapan International Standart Operation (ISO) dan Rencana Strategis (RESTRA) serta Rencana Kegiatan Awal Tahun (RKAT). Bentuk komunikasi dalam mengumpulkan zakat maal menggunakan sarana media online dan komunikasi tatap muka, dengan muzakki. Sedangkan Sosialisasi pengumpulan zakat maal dilakukan secara terus-menerus melalui program-program kerja mekanisme branding media online dan offline. Melalui strategi komunikasi ini Baznas Provinsi Jawa Barat berhasil meningkatkan jumlah pengumpulan zakat maal dari masyarakat.
\end{abstract}

Kata Kunci : Strategi Komunikasi; Sosialisasi; Zakat Maal; Badan Amil Zakat Nasional 


\section{PENDAHULUAN}

Zakat sebagai salah satu elemen dari rukun Islam tidak hanya memiliki dimensi ibadah namun lebih dari itu, zakat memiliki dampak yang lebih luas terhadap kehidupan sosial dan ekonomi masyarakat. Zakat sebagai salah satu instrumen ibadah terlihat dari sejumlah perintah zakat dalam Al Quran yang selalu disandingkan dengan perintah sholat. Setidaknya, terdapat delapan puluh dua perintah zakat yang selalu dikaitkan dengan perintah sholat.

Zakat sebagai salah satu instrumen redistribusi pendapatan telah dipraktikkan pada masa pemerintahan Rasulullah dan para sahabat. Dimana Zakat menjadi salah satu instrumen dalam kebijakan fiscal yang dialokasikan untuk menyantuni orang miskin dan juga menyediakan fasilitas dan segala kebutuhan bagi masyarakat miskin.

Perintah ambillah zakat dalam hal ini jelas ditujukan kepada Negara untuk mengambil zakat dari masyarakatnya. Hal ini berarti pula bahwa zakat merupakan satu satunya ibadah muamalah yang mempunyai petugas yaitu amil zakat. Cerita sukses zakat dalam upaya mengentaskan kemiskinan dapat kita lihat dari sejarah kejayaan masa pemerintahan Umar Bin Abdul Aziz. Pada masa pemerintahannya tidak lagi ditemukan masyarakat miskin yang berhak menerima zakat sehingga zakat dikirimkan ke negara tetangga yang membutuhkan.

Di Indonesia, pengelolaan zakat diatur oleh pemerintah melalui Undang-Undang pengolaan zakat, Undang-Undang No 23 Tahun 2011. Lembaga pemerintah yang berwenang untuk melakukan pengolahan dan pendistribusian zakat yaitu Badan Amil Zakat Nasional (BAZNAS) sampai ketingkat daerah. Provinsi Jawa Barat memiliki Badan Amil Zakat (BAZNAS) perwakilan pengumpulan zakat pada tingkatan daerah Provinsi di Jawa Barat.

Badan Amil Zakat Nasional (BAZNAS), lembaga nonstruktural yang dibentuk berdasarkan Undang-Undang No 23 Tahun 2011 tentang Pengelolaan Zakat. Pembentukan BAZNAS pertama kali ditetapkan dengan Keputusan Presiden No 8 Tahun 2001 tentang Badan Amil Zakat Nasional sesuai amanat Undang-Undang No 38 Tahun 1999 tentang Pengelolaan Zakat yang berlaku saat itu. Setelah perubahan regulasi BAZNAS berstatus sebagai lembaga pemerintah nonstruktural yang bersifat mandiri dan bertanggung jawab kepada Presiden melalui Menteri Agama. 
BAZNAS merupakan satu di antara sedikit lembaga nonstruktural yang memberi kontribusi kepada negara di bidang pembangunan kesejahteraan masyarakat dan penanggulangan kemiskinan melalui pengelolaan dana zakat. BAZNAS mendapat bantuan pembiayaan dari APBN sesuai ketentuan perundang-undangan, namun manfaat yang diberikan BAZNAS kepada negara dan bangsa jauh lebih besar. Dikaitkan dengan amanat UUD 1945 pasal 34 bahwa fakir miskin dan anak-anak terlantar dipelihara oleh negara , maka peran BAZNAS sangat menunjang tugas negara. BAZNAS berperan sebagai penyedia bantuan jaminan sosial bagi fakir miskin di tanah air. Kehadiran lembaga ini menopang tugas negara dalam mensejahterakan masyarakat, sehingga sewajarnya disokong oleh pemerintah.

Peran dan kontribusi Badan Amil Zakat Nasional kepada masyarakat, khususnya umat Islam, tidak hanya dalam ukuran yang bersifat kuantitatif, tetapi juga ukuran yang bersifat kualitatif, terutama peran Badan Amil Zakat Nasional dalam menyebarluaskan nilai-nilai zakat di tengah masyarakat. Yaitu nilai-nilai keimanan dan ketakwaan kepada Allah SWT, etos kerja, etika kerja dalam mencari rezeki yang halal dan baik, serta nilai-nilai zakat yang terkait dengan pembangunan karakter manusia (character building) sebagai insan yang harus memberi manfaat bagi sesama.

Menyusun sebuah strategi komunikasi adalah suatu seni, bukan sesuatu yang ilmiah, dan ada banyak cara pendekatan yang berbeda untuk melakukan tugas ini. Saran yang diberikan berikut ini hanyalah panduan yang tidak mempunyai aturan-aturan ketat. Sebelum seseorang memilih dan menggunakan strategi komunikasi yang tepat agar gagasan diperhatikan, dimengerti dan diikuti oleh orang lain yang menjadi sasarannya, dia harus memiliki pengetahuan yang cukup tentang apa yang akan disampaikan, mengapa harus disampaikan, dan efek yang diinginkan terjadi pada sasaran. Tanpa pengetahuan itu semua, pemilihan dan penggunaan strategi tidak dapat dilakukan, karena sebuah strategi hanya dapat digunakan untuk pesan dan hasil tertentu.

Dalam pelaksanaan tugas dan fungsi, BAZNAS provinsi wajib melakukan perencanaan, pelaksanaan, dan pengendalian atas pengumpulan, pendistribusian, dan pendayagunaan zakat ditingkat provinsi. Serta melakukan koordinasi dengan kantor wilayah kementrian agama provinsi dan instansi terkait ditingkat provinsi dalam pelaksanaan, pengumpulan, pendistribusian, dan pendayagunaan zakat. Dan Melaporkan dan mempertanggungjawabkan pengelolaan zakat, infak dan sedekah, serta dana sosial keagamaan lainnya kepada Badan Amil Zakat 
Nasional dan gubernur setiap 6 (enam) bulan dan akhir tahun. Melakukan verifikasi administrative dan faktual atas pengajuan rekomendasi dalam proses izin pembukaan perwakilan Lembaga Amil Zakat berskala nasional di provinsi. Badan Amil Zakat Nasional provinsi melaksanakan tugas dan fungsi Badan Amil Zakat Nasional di provinsi masing-masing sesuai dengan kebijakan Badan Amil Zakat Nasional (Baznas, 2014).

Pemerintah provinsi Jawa Barat dalam perananan mengentaskan permasalahan kemiskinan, keberadaan Tim Koordinasi Penanggulangan Kemiskinan Daerah (TKPKD) dapat membantu mengentaskan permasalahan kemiskinan Provinsi dan Kabupaten/kota yang ada di Jawa Barat. Efektivifitas tersebut, terdapat pada kesadaran membayar zakat maal sesuai dengan ketetentuan syariat dan penyaluran zakat secara benar melalui amil merupakan bentuk konsistensi muzakki terhadap perintah membayar zakat. Bentuk konsistensi merupakan penggambaran dari perilaku muzakki dalam membayar zakat maal secara terus menerus atau konsisten, yang dipengaruhi oleh tingkat keimanan, kredibilitas yang baik dari Badan Amil Zakat, dan kecenderungan lainnya yang dimiliki oleh muzakki.

Zakat, infak, sedekah dan dana sosial keagamaan lainnya yang dihimpun BAZNAS, disalurkan kepada orang-orang yang berhak menerima (mustahik) sesuai ketentuan syariat Islam. Penyaluran zakat diperuntukkan untuk 8 (delapan) asnaf, yaitu fakir, miskin, amilin, muallaf, gharimin, riqab, fisabilillah dan ibnu sabil. Penyaluran dana umat yang dikelola oleh Badan Amil Zakat Nasional dilakukan dalam bentuk pendistribusian (konsumtif) dan pendayagunaan (produktif). Selain menyantuni, Badan Amil Zakat Nasional menanamkan semangat berusaha dan kemandirian kepada kaum miskin dan dhuafa yang masih bisa bekerja agar tidak selamanya bergantung dari dana zakat.

Pengelolaan zakat oleh Badan Amil Zakat Nasional telah semakin berkembang baik dari sisi pengumpulan maupun pendistribusian dan pendayagunaannya. Pengumpulan dana zakat, infak dan sedekah pada Badan Amil Zakat Nasional mengalami peningkatan setiap tahun. Pelaksanaan pengumpulan zakat ketua Badan Amil Zakat Nasional (BAZNAS) wilayah Jawa Barat, Arif Ramdani menyampaikan. laporan perolehan zakat fitrah selama bulan Ramadhan tahun 201/1437 Hijriyah sebesar Rp. 214 Milliar (Rp. 214.636.56.720). Zakat maal telah terkumpul sebesar Rp. 26 Milliar (26.297.618.326), dan infaq sadakah menyentuh angka Rp. 13 Milliar. Total zakat firtah, zakat maal, infak dan sadaqah berjumlah Rp. 254 Milliar (Rp. 253.934.891.439), rekapitulasi zakat fitrah, 
zakat maal, infak dan sadakah tersebut dihimpun oleh BAZNAS kabupaten kota se-Jawa Barat dan kator wilayah kementrian Agama kementrian Provinsi Jawa Barat. Sedangkan zakat fitrah tahun 2015 berjumlah Rp. 175 miliar (Rp. 175.961.734.724) dari Tahun 2015- 2016 mengalami kenaikan sekitar Rp. 38 miliar atau sekitar 22 persen (Baznas, 2016).

Penyaluran zakat melalui Konter Layanan Mustahik (KLM) kepada masyarakat yang tergolong dhuafa diberikan dalam bentuk bantuan langsung berupa santunan. Santunan berupa pemenuhan kebutuhan dasar, seperti biaya hidup, sewa rumah, biaya pendidikan, biaya pengobatan, biaya transportasi dan pembayaran hutang konsumtif, biaya operasional panti, pondok pesantren, yayasan sosial. Penerima manfaat melalui KLM, setiap tahun mencapai kurang lebih 150.000 orang.

Selain Konter Layanan Mustahik, program kemanusiaan Badan Amil Zakat Nasional meliputi mitigasi bencana, seperti kebakaran, banjir, gempa bumi, tanah longsor dan bencana alam lainnya. Dalam bidang pendidikan, Badan Amil Zakat Nasional memiliki program beasiswa Satu Keluarga Satu Sarjana (SKSS) dan Dana Infak Anak Negeri (Dinar). Program SKSS tersebar di perguruan tinggi negeri (PTN) dan perguruan tinggi agama Islam negeri (PTAIN) seluruh Indonesia. Selain itu Badan Amil Zakat Nasional memberikan beasiswa S2 dan S3 dalam Program Kaderisasi Ulama. Di bidang ekonomi Bada Amil Zakat Nasional memberdayakan masyarakat melalui program Zakat Community Development (ZCD) yang mencakup pemberdayaan komunitas berbasis wilayah dan komunitas berbasis sosial. Penerima manfaat dana zakat, infak dan sedekah yang disalurkan Badan Amil Zakat Nasional harus memenuhi kriteria sebagai mustahik.

Secara umum tugas Badan Amil Zakat Nasional meliputi dua hal, yaitu sebagai operator dan koordinator pengelolaan zakat nasional. Untuk itu keamanahan, transparansi dan akuntabilitas menjadi perhatian Badan Amil Zakat Nasional sejak awal berdiri. Hasil audit Kantor Akuntan Publik atas Laporan Keuangan Badan Amil Zakat Nasional memberikan opini Wajar Tanpa Pengecualian (WTP) berturut-turut sejak 2001 sampai sekarang. Dalam bidang manajemen Bada Amil Zakat Nasional meraih sertifikat International Organization for Standardization (ISO) sejak 2009 dan terus dipertahankan hingga kini.

Keberhasilan Badan Amil Zakat Nasional dalam meningkatkan pengumpulan zakat dari muzakki pada kegiatan komunikasi secara efektif banyak ditentukan oleh penentuan strategi komunikasi para amil kepada muzakki, baik komunikasi interpersonal, intrapersonal maupun 
penyampaian isi pesan berkaitan dengan zakat maal yang disampaikan oleh amil Badan Amil Zakat Nasional Provinsi Jawa Barat.. Kepiawaian para amil zakat dalam berkomunikasi sangat menentukan keberhasilan pengumpulan zakat di Provinsi Jawa Barat. komunikasi efektif yang digunakan amil kepada muzakki dalam bingkai strategi komunikasi para amil zakat di Badan Amil Zakat Nasional Jawa Barat dapat berpengaruh besar kepada masyarakat terutama para muzakki untuk mengeluarkan zakatnya.

Badan Amil Zakat Nasional Provinsi Jawa Barat sendiri dipandang sudah melakukan tugasnya sesuai dengan tugas dan fungsinya sebagai lembaga pengumpulan zakat pada tingkatan provinsi di Jawa Barat. Sebagaimana telah membentuk unit pengumpulan zakat pada tataran wilayah kota dan kabupaten yang terdapat di Jawa Barat. Fenomena ini terlihat pada kota Bandung yang termasuk dalam wilayah Provinsi Jawa Barat, meluncurkan gerakan ayo bayar zakat pertama di Indonesia tentunya telah melaksankan tugas, fungsi dan kedudukan (Baznas, 2014b). Sebagai bagian dari wilayah Jawa Barat. Persoalan tersebut sesuai dengan apa yang telah dicanangkan oleh walikota Bandung Ridwan Kamil dengan gerakan Ayo Bayar Zakat (Bandung, 2016).

Penelitian tentang pengelolaan zakat pernah dilakukan di Provinsi Sumatera Selatan. Berdasarkan hasil penelitian Hasanah (2005) Badan Amil Zakat Nasional Sumatera Selatanm melakukan pengelolaan penghimpunan dengan tiga cara yaitu sosialisasi, kerja sama, dan pemanfaatan rekening bank. Penghimpunan zakat tersebut telah dilakukan secara efektif tetapi belum optimal karena Badan Amil Zakat (BAZNAS) Sumatera Selatan tidak melakukan penghimpunan secara langsung kepada mustahik. Demikian juga dalam kegiatan pendistribusian Baznas Sumatera Utara telah melakukannya melalui program-program unggulan seperti Sumsel Peduli, Sumsel Sehat, Sumsel Makmur, Sumsel Taqwa, dan Sumsel Cerdas.

Demikian juga penelitian dilakukan di Badan Amil Zakat Nasional (BAZNAS) Di Kota Padang. Mishbah El Yaser (Yaser, 2016), melihat kurangnya upaya komunikasi persuasi yang dilakukan oleh badan pengelola zakat kepada masyarakat di Kota Padang, sehingga masyarakat tidak berminat menyalurkan zakatnya ke badan pengelola zakat tersebut. Badan Amil Zakat Nasional Kota Padang melalui bidang humasnya kemudian menggalakkan kampanye berzakat kepada masyarakat. mempengaruhi, meyakinkan, dan 
mengajak masyarakat beralih untuk menyalurkan zakat ke Badan Amil Zakat Nasional. Melalui aktivitas Humas Badan Amil Zakat Nasional berupa publikasi dan event, serta penyuluhan, aktivitas tersebut mampu merpersuasi masyarakat dan menarik minat masyarakat untuk menyalurkan zakat ke Badan Amil Zakat Nasional.

manajemen pendistribusian zakat juga diteliti di Rumah Zakat Bandung (Rahmayati, 2013). Rumah Zakat melakukan pendistribusian zakat melalui manajemen pendistribusian zakat. Perencanaan yang digunakan oleh Rumah Zakat adalah perencanaan bisnis atau bisnis plan, pelaksanaannya dalam pendistribusian di Rumah Zakat ini dengan cara memberikan modal usaha kepada mustahiq dan pengawasan yang dilakukan oleh Rumah Zakat ialah pengawasan terhadap mustahiq dengan cara mengontrol perkembangan usaha yang telah dijalankan oleh mustahik, dan yang kedua pengawasan terhadap tim penyalur zakat, sehingga dana zakat yang diberikan tepat pada sasaran.

Penelitian tentang pengelolaan zakat masih sedikit yang diangkat dari sudut pandang ruang lingkup komunikasi. Berdasarkan latar belakang diatas, tulisan ini ingin mengungkapkan tentang strategi komunikasi Badan Amil Zakat Nasional Provinsi Jawa Barat dalam bentuk bagaimana manajemen komunikasi, bentuk komunikasi dan sosialiasi pengumpulan zakat maal yang dilakukan Baznas Provinsi Jawa Barat. Dengan pendekatan komunikasi ini diharapkan penelitian ini bisa memperkaya upaya Badan Amil Zakat Nasional dalam pengumpulan zakat dari masyarakat.

Penelitian ini menggunakan paradigma interpretatif karena kajian yang diteliti menyangkut dimensi manusia khususnya masyarakat dalam mengumpulkan zakat di Baznas. Jenis penelitiannya adalah deskriptif kualitatif untuk memahami dan mendeskripsikan fenomena di Badan Amil Zakat Provinsi Jawa Barat, khususnya dalam kegiatan manajemen komunikasi, bentuk komunikasi, dan sosialisasi dalam mengumpulkan zakat maal.

\section{HASIL DAN PEMBAHASAN}

Badan Amil Zakat Nasional Provisi Jawa Barat merupakan Lembaga formal yang berwenang menghimpun dan mendistribusikan Zakat, Infak, sedekah dan Dana sosial keagamaan lainnya. Berawal dari Unit Pengumpuan Zakat (UPZ) di Lingkungan Pemerintah Provinsi Jawa Barat, untuk menghimpun dana ZIS dari PNS dan Pegawai yang ada 
di lingkungan pemerintah provinsi Jawa Barat, dengan idealisme dari mereka untuk mereka, kemudian Pada Masa Kepemimpinan Bpk. H. Ahmad Heryawan (Kang Aher) diperkuat dengan Peraturan Gubernur dan edukasi yang terus menerus tentang kesadaran berzakat, bersamaan dengan dikukuhkannya Pengurus Badan Amil Zakat Daerah (BAZDA) Jawa Barat, sehingga penghimpunan dana ZIS semakin optimal dan menyentuh semua Pegawai Negeri Sipil (PNS) yang sudah mencapai nishab Zakat (wawancara Ramdani, 4 April 2017).

Pengurus Badan Amil Zakat Daerah (BAZDA) Jawa Barat dipimpin oleh KH. Arif Ramdani, $\mathrm{MH}$ dengan program kerja bidang pengumpulan meliputi Pembentukan UPZ, Gathering Muzaki, Happening Art, Open Table (Konter Layanan ZIS) di Pusat keramaian dan Asrama haji, Pengadaan Kontak Infak, Infak Autodebet via ATM, Sosialisasi dan kerjasama dengan televisi, radio, spanduk, koran, media sosial, dll (Baznas, 2016). Sedangkan program unggulan Baznas Provinsi Jawa Barat diantaranya Jabar Cerdas, Jabar Mandiri, Jabar Taqwa, dan Jabar Peduli.

Penelitian ini akan menitik beratkan pada kegiatan manajemen komunikasi bentuk komunikasi dan sosialiasi pengumpulan zakat maal yang dilakukan Baznas Provinsi Jawa Barat.

\section{Manajemen Komunikasi Badan Amil Zakat Nasional Provinsi Jawa Barat}

Persoalan manajemen biasanya menjadi masalah bagi sebagian masyarakat awam yang belum mengetahui prosedur-prosdur yang telah ditetapkan pada Badan Amil Zakat seperti Badan Amil Zakat Nasional Provinsi Jawa Barat. Mengikuti proses manajemen strategi Fred R David (2006) proses manajemen strategi bisa dilihat dalam tiga tahapan, yaitu memformulasikan strategi, mengimplementasikan strategi dan mengevaluasi strategi.

Pertama, tahap formulasi. Strategi. Badan Amil Zakat Provinsi Jawa Barat dalam menghadapi perkembangan zaman kekinian melakukan formulasi strategi dengan mengubah mindside paradigma dari sebuah lembaga yang tradisional dan konvensional menjadi lembaga yang modern berbasis Informasi Teknologi (IT). Karena jika tidak mengikuti perkembangan zaman Badan Amil Zakat Provinsi Jawa Barat akan ketinggalan (Wawancara Arif Ramdani, 4 April 2017). 
Masyarakat dan pengusaha menurut Ramdani ingin kemudahan dalam mengakses lembaga zakat karena mereka memiliki aktivitas yang cukup padat dan mobilitas yang tinggi. Baznas Provinsi Jawa Barat memberi kemudahan dengan teknologi, berzakat memakai Handphone. Aplikasi zakat di handphone mempermudah akses masyarakat untuk melihat program-program Badan Amil Zakat Provinsi Jawa Barat.

Untuk mendukung formulasi yang dicanangkan Badan Amil Zakat Provinsi Jawa Barat dibuatlah beberapa program yaitu: 1) mengupgrade Sumber Daya Manusia di Badan Amil Zakat Nasional Provinsi Jawa Barat dengan pelatihan-pelatihan berbasis teknologi mendukung program-program Badan Amil Zakat Nasional yang berrbasis Informasi Teknologi, 2) menyiapkan perangkat pendukung teknologi di Badan Amil Zakat Provinsi Jawa Barat, agar menunjang kinerja dalam pengumpulan zakat maal berbasis tehnologi. Badan Amil Zakat Nasional sudah menyiapkan hal ini sedemikian rupa supaya tercapaiya optimalisasi pengumpulan zakat maal. 3) melakukan kerjasama kemitraan (partnership) dengan berbagai pihak baik dalam pengumpulan, pendistribusisan dan pendayagunaan zakat, melalui zero interest atau ikhlas, sehingga tidak ada interest pribadi yang dapat merugikan dan mendzolimi mustahik. 4) mengembangkan budaya kerja yang amanah, professional, antusias, komunikatif. Melalui nilai-nilai budaya kerja ini di harapkan amil pelaksana betulbetul memikul amanah mereka dengan baik untuk mencapai visi dan misi Baznas Provinsi Jawa Barat.

Peningkatan Sumber Daya Manusia Profesional Badan Amil Zakat Nasional Provinsi Jawa Barat, melakukan dua cara yaitu: secara prilaku dikuatkan dengan kode etik amil, tatib dan sebagainya. Apa yang boleh dilakukan mereka apa yang dilarang dan lain sebagainya. Dan secara kompetensi ada sertifikasi amil, Badan Amil Zakat Pusat sudah mulai memikirkan mensertifikasi amil, sehingga amil itu strandarisasi kemampuannya tidak asal-asalan.

Upaya formulasi Baznas ini merupakan bagian dari manajemen atau kemampuan mengarahkan dan mencapai hasil yang diinginkan dengan pemberdayaan manusia dan sumber daya lainnya. Sebagaimana diungkapkan oleh Terry "Manajement is performance of conciving desired results by means of group efforts consisting of utilizing human talent and resources" (Syafaruddin, 2005). 
Persoalan komunikasi terkait ruang komunikasi formal Badan Amil Zakat Nasional Provinsi Jawa Barat, selain menerapkan formulasi pada sumber daya manusia yang ada saat ini. Melakukan komunikasi formal dengan pemerintah Provinsi Jawa Barat, mekanisme komunikasi ini dilakukan terkait dengan pengelolaan Zakat. Adapun Tentang pelaksanaannya mengacu pada UU no.23 tahun 2011 tentang Pengelolaan Zakat dan dikuatkan melalui PP No 14 tahun 2014 tentang pelaksanaan UU no 23 tahun 2011 tentang Pengelolaan Zakat. Melakukan komunikasi formal dengan SKPD Provinsi Jawa Barat, Instansi Vertikal seperti kantor wilayah kementrian Agama, kantor keuangan, kantor pajak, Perguruan Tinggi, Badan Usaha Milik Daerah dan Masjid Agung Provinsi (Wawancara: Dita Agustina, 16 Maret 2017)

Proses tersebut dilakukan amil zakat Badan Amil Zakat Nasional Provinsi Jawa Barat. Komunikasi formal berupa, pemberian surat dengan mengundang kepada SKPD Provinsi Jawa Barat, kantor pajak, kantor keuangan, Perguruan Tinggi, Badan Milik Usaha Daerah. Mengajak mereka audiensi guna tercapainya kegiatan Badan Amil Zakat mengajak mereka menjadi mustahik bagi yang telah mencapai nisab. Kemudian mengadakan pelatihan-pelatihan didalamnya atas persetujuan dari mereka.

Komunikasi non formal yang terjadi secara spontan, misalnya sumbang saran yang berkaitan dengan tugas, kewajiban. Efektif digunakan dalam perusahaan yang bersifat padat karya dengan jumlah pekerja cukup banyak, dan tidak terlalu teknis biasaya terjadi pada saat konsultasi tentang pelayanan zakat dikantor layanan muzakki dan beranda zakat pada saat mahasiswa melakukan penelitian. Hal ini dilakukan karena Badan Amil Zakat Nasional menerapkan pada setiap amil agar antusias dalam kondisi apapun terkait dengan permasalahan umat dan menanggapi persoalan tersebut dengan komunikatif.

Badan Amil Zakat Nasional Provinsi Jawa Barat juga melakukan komunikasi non formal namun lebih menekankan pada aspek human relationsnya. Atau dengan kata lain digunakan dalam permasalahan diluar pekerjaan secara langsung, seperti komunikasi jaringan pribadi, Keluarga, maupun kerabat dekat dari setiap ketuaketua Badan Amil Zakat Nasional Provinsi Jawa Barat.

Terkait Komunikasi teknis biasanya hanya dilakukan dan dimengerti oleh orang-orang tertentu saja yang berkaitan dengan kegiatan tersebut. pada persoalan ini Badan Amil Zakat Nasional 
Provinsi Jawa Barat telah mempersiapkan para amil yang mengerti Job Deskription masing-masing dari setiap Pengurus Badan Amil Zakat Nasional Provinsi Jawa Barat (wawancara Dita Agustina, 16 Maret 2017.

Kedua, Tahap Implementasi. Implementasi dari kegiatan pengumpulan zakat dilakukan pada proses pengembangan perluasan daerah pengumpulan zakat maal. terkhusus pimpinan antar lembaga sebagai wajahnya adalah pimpinan Badan Amil Zakat Nasional Provinsi Jawa Barat. Biasanya setiap ketua memiliki jaringan pribadi. Telkom, memanfaatkan jaringan pribadi pimpinan atau kepala devisi guna memperbanyak relasi. mengingatkan para mustahik dengan menggunakan email blaz dari SIMBA, sms blaz dari SIMBA, melalui media tersebut Badan Amil Zakat Nasional Provinsi Jawa Barat khususnya bidang pengumpulan. Mengingatkan para muzakki melalui sms blaz sehingga dapat mengingatkan lebih banyak mustahik lebih banyak pada setiap bulannya, agar tercapainya target pengumpulan zakat maal (Wawancara Dita Agustina, 16 Maret 2017).

Adapun pelaksanaan di lapangan baik teknik dan non teknis pada persoalan ini sudah dipersiapkan secara internal pengurus Badan Amil Zakat Nasional Provinsi Jawa Barat. Merujuk kinerja Badan Amil Zakat Nasional Provinsi Jawa Barat dalam mengimplementasikan program yang sudah dirumuskan. Merujuk pada ruh dan spirit dari kegiatan Badan Amil Zakat Nasional ada lima aspek penting dibawah ini (wawancara Arif Ramdani 4 April 2017):

Pertama, sosialisasi dan edukasi zakat kepada seluruh masyarakat secara berjenjang dan terstruktur. Sehingga kegiatan zakat dirasakan getarannya oleh seluruh masyarakt. Sosialisasi tentang hikmah tujuan dan manfaat zakat bagi pembangunan karakter dan kesejahteraan bangsa. Kaitan zakat dengan berbagai dimensi kehidupan, termasuk kegiatan ekonomi dan keharusan berzakat melalui amil zakat. Program sosialisasi dan edukasi zakat didukung oleh pemerintah melalui Undang-undang No.23/201/2011 tentang Pengelolaan Zakat Peraturan Pemerintah (PP) NO.14/2014 tentang Pengelolaan Zakatdan Inpres No 3/2014 tentang Optimalisasi pengumpulan zakat melalui BAZNAS pusat maupun daerah.

Kedua, Penguatan BAZNAS sebagai amil, menyangkut Sumber Daya Manusia yang memiliki integritas pribadi yang kuat, amanah, dan professional. Selain itu juga harus memiliki pengetahuan tentang zakat dan manajemennya yang memadai dan memiliki waktu yang 
cukup. Sistem Informasi Teknologi lembaga harus juga canggih, memiliki database muzakki dan mustahik yang akurat. Serta koordinasi yang baik antara Badan Amil Zakat Nasional ditingkat Pusat.

Ketiga, program pendayagunaan zakat yang tepat sasaran, baik konsumtif maupun produktif skala prioritas yang sejalan dengan kebutuhan mustahik di daerah masing-masing. Perencanaan, pelaksanaan dan evaluasi program yang dilakukan secara tepat.

Keempat, penguatan regulasi dan aturan tentang pengelolaan zakat. Menguatkan dan menjabarkkan ketiga aturan tersebut diatas ditambah dengan peraturan-peraturan Badan Amil Zakat Nasional, agar semuanya berjalan dengan koordinasi yang baik.

Kelima, sinergi dan koordinasi dengan semua pihak, termasuk dengan Lembaga Amil Zakat (LAZ) pusat maupun daerah, dengan ormas Islam, dengan lembaga pendidikan, dengan masjid-masjid dan pondok pesantren serta semua simpul-simpul masyarakat (Hafidhuddin : 2009).

Tahap implementasi ini merupakan bagian yang krusial , karena merupakan keputusan dari pihak yang berwenang dalam mengambil keputusan untuk menetapkan tujuan tahunan, membuat kebijakan, memotivasi pegawai, dan mengalokasikan sumberdaya yang dimiliki sehingga strategi yang sudah diformulasikan dapat dilaksanakan. Sebagaimana diungkapkan David (2006: 5) tahap ini dilakukan pengembangan strategi pendukung budaya, merencanakan struktur organisasi yang efektif, mengatur ulang usaha pemasaran yang dilakukan, mempersiapkan budget, mengembangkan utilisasi system informasi serta menghubungankan kompensasi karyawan terhadap kinerja organisasi.

Ketiga, Tahap Evaluasi. Evaluasi strategi memiliki tiga aktifitas yang fundamental, yaitu mereview faktor-faktor internal dan eksternal yang menjadi dasar untuk strategi saat ini. Mengukur performa dan mengambil langkah korektif. Fred R. David (2006: 5)menjelaskan strategi utama suatu organisasi dilakukan melalui tiga tahapan kerangka kerja dengan matrik sebagai model analisisnya. Matrikmatrik tersebut disesuai dengan segala ukuran dan tipe organisasi, sehingga dapat dipakai dalam mengidentifikasi, mengevaluasi, dan memilih strategi-strategi yang paling tepat.

Berdasarkan konsep Fred R. David formulasi Badan Amil Zakat Nasional Provinsi Jawa Barat telah dilakukan baik dalam komunikasi 
formal melalui instruksi-insruksi pimpinan yang berbentuk lisan maupun tulisan berjalan sesuai prosedur secara fungsionaris Badan Amil Zakat Nasional Provinsi Jawa Barat.

Adapun komunikasi non formal yang terjadi secara spontanitas, berkaitan sumbang saran berkaitan dengan tugas dan kewajiban Badan Amil Zakat Nasional Provinsi Jawa Barat. Persoalan komunikasi yang bersifat spontanitas ini secara efektif digunakan dalam perusahaan dalam kerjasama yang bersifat padat karya dengan jumlah pekerja cukup banyak sudah berjalan sebagaimana mestinya, namun masih perlu pengembangan-pengembangan dari segi Sumber Daya Manusia yang ada di Badan Amil Zakat Provinsi Jawa Barat.

Komunikasi non formal yang digunakan pada persoalan diluar pekerjaan secara langsung atau human relations, secara regulasinya terletak pada para ketua-ketua Badan Amil Zakat Nasional Provinsi Jawa Barat pada setiap regulasi kepemimpinannya. Persoalan ini digunakan sebagai bentuk arahan yang langsung ditunjuk secara pribadi para ketua menggunakan jaringan yang dimililkinya secara komunikasi yang telah berlangsung lama.

Pada persoalan ini tidak ada keraguan didalamnya dikarenakan memperluas wilayah pengumpulan zakat maal melalui jalur pribadi para pimpinan Badan Amil Zakat Nasional Provinsi Jawa Barat (wawancara Dita Agustina 16 Maret 2017). Sedangkan komunikasi teknis biasanya hanya dilakukan dan dimengerti oleh orang-orang tertentu saja yang berkaitan dengan kegiatan dan job description pada masingmasing bidang-bidang pengumpulan, pendistribusian, pendayagunaan dana zakat yang dilakukan secara professional, amanah sesuai dengan kode etik amil.

Lebih lanjut Badan Amil Zakat Nasional Provinsi Jawa Barat sangat memperhatikan proses komunikasi prosedural ini. Bentuk komunikasi ini biasanya dekat dengan komunikasi formal, perwujudan tersebut dalam bentuk laporan tahunan atau bulanan, instruksi tertulis, memo, font evaluasi kinerja dan sebagainya (wawancara Arif Ramdani, 4 April 2017).

Penguatan dalam menjaga evaluasi pengurus Badan Amil Zakat Nasional provinsi Jawa Barat, untuk memenuhi prinsip dasar syariat Islam, yaitu kewajiban Amil Zakat memegang prinsip dasar terintegrasi, prinsip dasar professional, prinsip dasar transparansi, dan prinsip dasar sinergi. Ini sesuai dengan kode etik amil pada Berdasarkan kode etik amil Bab III Pelaksanaan Prinsip Dasar pasal 3 
tentang prinsip-prinsip dasar dalam pengelolaan zakat yaitu : 1) Syariat Islam, artinya dalam menjalankan tugas dan fungsinya, amil zakat haruslah berpedoman sesuai dengan syariat Islam, mulai dari tata cara perekrutan pegawai hingga tata cara pendistribusian zakat. 2) Amanah dan integritasartinyasetiap lembagapengelola zakat haruslah menjadi lembaga yang dapat dipercaya. Setiap amil memiliki pemikiran, perkataan, dan tindakan yang baik dan benar dengan memegang teguh kode etik dan prinsip-prinsip moral. 3) Kemanfaatan artinya organisasi pengelola zakat harus mampu memberikan manfaat yang besar bagi mustahik. 4) Keadilan artinya dalam mendistribusikan zakat harus mampu bertindak adil, yaitu sikap memperlakukan secara setara di dalam memenuhi hak-hak yang timbul berdasarkan perjanjian serta peraturan-perundangan yang berlaku. 5) Kepastian hukumartinya muzaki dan mustahik harus memiliki jaminan dan kepastian hukum dalam proses pengelolaan zakat. 6) Terintegrasi artinya pengelolaan zakat harus dilakukan secara hierarkis sehingga mampu meningkatkan kinerja pengumpulan, pendistribusian dan pendayagunaan zakat. 7) Akuntabilitas artinya pengelolaan zakat harus bisa dipertanggungjawabkan kepada masyarakat dan mudah diakses oleh masyarakat dan pihak lain yang berkepentingan. 8) Profesional artinya perilaku yang selalu mengedepankan sikap dan tindakan yang dilandasi oleh tingkat kompetensi, kredibilitas, dan komitmen yang tinggi. 9) Transparansi artinya tindakan menyampaikan informasi secara transparan, konsisten, dan kredibel untuk memberikan layanan yang lebih baik dan lebih cepat kepada pemangku kepentingan. 10) Sinergi artinya sikap membangun dan memastikan hubungan kerja sama internal yang produktif serta kemitraan yang harmonis dengan para memangku kepentingan zakat, untuk menghasilkan karya yang bermanfaat dan berkualitas.

Analisis strategi tersebut mengikuti konsep Fred R. David (2006: 5) bertujuan untuk menyimpulkan informasi dasar yang diperlukan untuk memunculkan strategi-strategi alternatif yang dapat dilaksanakan melalui penggabungan faktor eksternal dan internal, dan untuk menggunakan input informasi dari tahap 1 untuk mengevaluasi secara objektif strategi-strategi alternatif dari hasil tahap 2 yang dapat diimplementasikan, sehingga bisa memberikan suatu basis objektif bagi pemilihan strategi-strategi yang paling tepat.

Persoalan manajemen komunikasi dalam mengumpulkan zakat maal, Badan Amil Zakat Nasional Provinsi Jawa Barat menggunakan 
International Standart Operation (ISO) dalam proses prosedur pengumpulan zakat maal. Terkait Implementasi dari ISO Dilakukan dengan RESTRA (Rencana Strategis) dan RKAT (Rencana Kegiatan Awal Tahun). Hal ini dibuktikan dengan kode etik yang telah dirumuskan oleh Badan Amil Zakat Nasional Provinsi Jawa Barat guna menjaga prinsip dasar terintegrasi, prinsip dasar akuntabilitias, prinsip dasar professional, prinsip dasar transparansi dan prinsip dasar sinergi. Agar tercapainya visi misi Badan Amil Zakat Nasional Provinsi Jawa Barat sesuai dengan tugas dan fungsinya sebagai tempat pengumpulan, pengelolaan, pendistribusian, penyaluran zakat secara umum, maupun zakat maal yang sesuai dengan syariat Islam, mulai dari tata cara perekrutan pegawai hingga tata cara pendistribusian zakat.

\section{Bentuk Komunikasi Badan Amil Zakat Nasional Provinsi Jawa Barat}

Manajemen komunikasi Badan Amil Zakat Provinsi Jawa Barat pada bidang pengumpulan menggunakan bentuk komunikasi terkhusus. Agar tercapainya target pengumpulan zakat maal yang efektif dan efesian, Badan Amil Zakat Provinsi Jawa Barat memaksimalkan pengumpulan dan pengelolaan dana zakat dari masyarakat dari pemerintah maupun dari unit usaha.

Bentuk komunikasi yang dilakukan pada bidang pengumpulan dalam hal pengumpulan dana zakat secara umum maupun zakat maal yakni dengan memanfaatkan perkembangan tekhnologi yang ada pada era ini, yaitu Online melalui media sosial, internet, transfer, internet banking untuk mengumpulkan dana zakat secara umum dan zakat maal dari masyarakat yang telah mencapai nisab, dan Sosialisasi proses pengumpulan dana zakat secara umum maupun khususnya zakat maal, pada saat ini cukup banyak (wawancara Dita Agustina, 16 Maret 2017).

Bentuk sosialisasi dalam upaya pengumpulan dana zakat maupun zakat maal tersebut diantaranya: 1) mengundang seluruh kampus yang ada di Prrovinsi Jawa Barat beserta Rektor-rektornya, 2) memberikan surat udangan kepada instansi- instansi yang ada di wilayah Provinsi Jawa Barat, 3) penyebaran 1000 kotak infaq di wilayah kerja Badan Amil Zakat Nasional Provinsi Jawa Barat. Disebarkan kampus, instansi,dan masyarakat, 4) jemput zakat, Jika muzakki tidak sempat bayar zakat petugas menjemput zakat minimal 
500 ribu rupiah untuk dalam kota, luar kota sesuai dengan jauh dekatnya, 5) muzakki bisa datang langsung ke konter layanan muzakki, untuk bayar sendiri sampai mendapatkan Nomor Pokok Wajib Zakat (NPWZ) diberikan bukti stor zakat bisa pengurang penghasilan kena pajak, dikarenakan bukti stor zakat tersebut bisa menjadi pengurang penghasilan kena pajak. Meskipun belum pengurang penghasilan kena pajak (wawancara Dita Agustina, 16 Maret 2017).

Secara garis besar pengumpulan zakat maal dari instasi pemerintah dan masyarakat belum bisa secara optimal dilakukan pengumpulan dana zakat maupun zakat maal online. Dikarenakan persoalan ini pengumpulan dana zakat maupun zakat maal sebagian besar dari offline.

Badan Amil Zakat Nasional Provinsi Jawa Barat telah membentuk lembaga-lembaga atau instansi yang sudah ditentukan yaitu di PP NO 142014 tentang pelaksanaan UU 23 UPZ guna sebagai pedoman pembentukan Unit Pengumpul Zakat (UPZ).

Adapun yang boleh dibentuk oleh Badan Amil Zakat Nasional Provinsi Jawa Barat diantaranya: SKPD atau dinas-dinas pemerintahan provinsi, Instansi Vertikal seperti Kantor Wilayah, kantor wilayah keuangan, Pajak yang ada kanwil-kanwilnya Badan Amil Zakat Provinsi Jawa Barat berwenang membentuk kantor Unit Pengumpul Zakat dikantor wilayah tersebut.

Dalam pengumpulan zakat maal di Badan Amil Zakat Provinsi Jawa Barat pada tataran teori terdapat dua tatanan dalam menentukan efek apa yang ingin dicapai: Pertama, Komunikasi Tatap Muka. Komunikasi ini dipergunakan apabila kita mengharapkan efek perubahan tingkahlaku (behaviour change) dari komunikan. Mengapa demikian karena sewaktu berkomunikasi memerlukan umpan balik langsung. Dengan saling melihat, kita sebagai komunikator bisa mengetahui pada saat kita berkomunikasi komunikan memperhatikan kita dan mengerti apa yang kita komunikasikan.

Komunikasi tatap muka yang masih diterapkan oleh Badan Amil Zakat Nasional Provinsi Jawa Barat masih lakukan sampai saat ini, hal ini dikarenakan pengumpulan dana zakat terbesar pada bidang pengumpulan zakat terdapat pada komunikasis langsung dengan para muzakki. Sehingga model komunikasi bermedia cendung belum bisa dilakukan secara optimal. 
Sebagaimana Komunikasi tatap muka memerlukan bahasa agar fungsi komunikasi mudah dimengerti, Menurut Larry L. Barker (Mulyana, 2007), bahasa mempunyai tiga fungsi yaitu penanaman (naming atau labeling), iteraksi, dan transmisi informasi. Penanaman atau penjulukan merujuk pada usaha mengidentifikasikan objek, tindakan atau orang denga menyebut namanya sehingga dapat dirujuk dalam komunikasi. Fungsi interaksi menekankan berbagai gagasan dan emosi, yang dapat mengundang simpati dan pengertian atau kemarah dan kebingungan. Melalui bahasa, informasi dapat disampaikan kepada orang lain, inilah yang disebut fungsi tranmisi dari bahasa. Keistimewaan bahasa sebgai fungsi transmisi informasi yang lintas waktu dengan menghubungkan masa lalu, masa kini dan masa depan, memungkinkan kesinambungan budaya dan tradisi kita (Mulyana, 2007: 267).

Kedua, Komunikasi Bermedia. Pada umumnya banyak digunakan untuk komunikasi informatif. Ketika tidak memerlukan efek dalam bentuk perubahan tingkah laku, maka dapat digunakan atau diambil media massa, jadi, tergantung dari situasi dan kondisi dan efek yang diharapkan.

Dalam proses komunikasi yang dilakukan Badan Amil Zakat Nasional Provinsi Jawa Barat dalam mengumpulkan Zakat Maal, dilakukan dengan cara, yaitu: 1) Mengakselerasi pengumpulan dengan memanfaatkan media sosial, media online, dan media massa, seperti spanduk billboard, media massa online ( Gala Media Online), Berita Langitan, meida cetak. Penandatangan Mou telah dilakukan dengan Gala Media, Radio L Sinta, PR FM terutama pada bulan Ramadan. Untuk Televisi belum dilakukan karena biaya yang cukup besar. 2) Marketing BAZNAS, marketing Badan Amil Zakat Nasional Provinsi Jawa Barat dilakukan guna mensosialisasikan program-program BAZNAS kepada masyarakat. Kegiatan tersebut dilakukan pada bulan Ramadhan.. Dengan menggunakan media meja sebagai stan promosi Badan Amil Zakat Nasional Provinsi Jawa Barat,berisikan media sosialisasi flayer, produk BAZNAS, Al. Qur’an, bingkisan- bingkisan Ramadhan, dan berbagi buka puasa. Proses sosialisasi ini dilakukan di mall dan tempat keramaian. 3) Happening Art ( Hari Besar). Biasa dilakukan pada peringatan hari besar Islam dengan mengundang anak yatim mengundang anak- anak duafa, keliling mempromosikan Badan Amil Zakat Nasional Provinsi Jawa Barat. Kegiatan ini dilakukan dengan membagikan flayer, spanduk keliling mengelilingi jalan suci 
sampe dipenogoro dalam acara happening art. Proses marketing yang dilakukan Badan Amil Zakat Provinsi Jawa Barat lakukan dilapangan yang melibatkan orang banyak, optimallisasi pemasangnan spanduk dibatasi maksimal 50 spanduk dikarenakan sudah ada aturan pemerintah yang mengatur hal tersebut (wawancara: Dita Agustina, 16 Maret 2017).

Persoalan hubungan antara manajemen strategi dan manajemen komunikasi terhadap visi dan misi terhadap formulasi, implementasi dan evaluasi yang digunakan Badan Amil Zakat Nasional Provinsi Jawa Barat. Sangat berefek pada proses sosialisasi yang dilakukan Badan Amil Zakat Nasional Provinsi Jawa Barat dalam mengumpulkan zakat maal. Jika formulasi yang digunakan tidak kreatif, implementasi program tidak berjalan secara massif apalagi ditambah evaluasi hanya dijadikan proses birokrasi saja. Maka proses komunikasi dalam pengumpulan dengan menggunakan media baik oflline maupun online akan mendapatkan kendala terutama bagi para muzakki maupun masyarakat.

Untuk mengukur keberhasilan dalam pengumpulan zakat maal yang dilakukan Badan Amil Zakat Nasional Provinsi Jawa Barat dengan mensosialisasikan setiap program Badan Amil Zakat Nasional tersebut dengan sosialisasi kepada masyarakat. Persoalan ini sangat berefek pada masyarakat maupun muzakki dalam menyetorkan zakat maal di Badan Amil Zakat Nasional Provinsi Jawa Barat (wawancara Dita Agustina, 16 Maret 2017).

Menurut Belch George dan Belch Michael, komponenkomponen dalam efek kognitif untuk menunjang pengumpulan yaitu: 1) Kesadaran. Sebagian besar audience sasaran tidak menyadari merek, produk atau jasa, yang ditawarkan, tugas perusahaan adalah membagun kesadaran. Kesadaran berarti bahwa pesan yang telah dibuat menimbulkan kesan kepada pembaca atau penonton yang kemudian dapat membantu mengidentifikasi pembuat pesan. Tahapan program-program, sosialisasi menggunakan media online maupun media massa dan tatap muka dengan datang langsung kepada muzakki yang mengalami kendala dalam proses pengumpulan zakat maal. Pada proses kesadaran ini, Badan Amil Zakat Nasional Provinsi Jawa Barat berkerjasama dengan Ulama, Ustadz dan Penceramah untuk menyampaikan materi-materi ceramahnya tentang masalah zakat secara umum dan zakat maal secara khusus. 2) Pengetahuan. Audience mungkin telah memiliki kesadaran, tetapi tidak mengetahui lebih 
banyak lagi. Dan memiliki tugas untuk memberikan informasi sebanyak-banyaknya sehingga audience sasaran memiliki "pengetahuan tentang produk, manfaat, faedah guna, dan keuntungan, serta bagaimana cara menggunakan produk" (George \& Michael, 2007).

\section{Sosialisasi Badan Amil Zakat Nasional Provinsi Jawa Barat dalam Mengumpulkan Zakat Maal}

Penyampaian program- program kepada masyarakat luas Badan Amil Zakat Nasional Provinsi Jawa Barat menggunakan media online digunakan sebagai media sosialisasi sebagai salah satu upaya mengumpulkan zakat maal di wilayah kerja provinsi Jawa Barat. Proses tersebut dilakukan agar masyarakat Jawa Barat dapat mengakses informasi-informasi yang disimpaikan terkait dengan cara membayar zakat maal.

Sosialisasi pada persolanan pengumpulan zakat maal dipandang penting, dikarenakan sudah menjadi kewajiban Badan Amil Zakat Nasional Provinsi Jawa Barat sebagai lembaga amil zakat di provinsi Jawa Barat. Sosialisasi tersebut juga tidak hanya dilakukan pada media online saja, terkait pengumpulan zakat maal bidang pengumpulan juga menggunakan media sosialisasi berupa media offline.

Dalam proses ini bidang pengumpulan zakat maal Provinsi Jawa Barat selaku Amil Zakat tak lepas dari komunikasi sebagai saluran untuk mencapai target pengumpulan zakat maal disetiap tahunnya. Terkait persoalan sosialisasi tidak hanya dilakukan dalam momentum masa panen seperti di bulan Ramadhan, Bidang pengumpulan melakukan sosialisasi pengumpulan secara terusmenerus guna tercapainya sosialisasi pengumpulan kepada masyarakat.

Proses sosialiasi melalui media komunikasi tersebut dilakukan karena komunikasi merupakan proses interaksi antara komunikator dan komunikan. Dalam proses ini secara garis besar Kotler membagi saluran komunikasi menjadi dua yaitu: 1) Saluran komunikasi Pribadi (personal) mencakup dua atau lebih orang berkomunikasi secara langsung satu sama lain. Mereka dapat bertatap muka, telepon, surat elektronik, atau chatting melalui internet. Saluran ini memungkinkan komunikasi pribadi dan mendapatkan umpan balik. Pada Saluran Komunikasi Pribadi Badan Amil Zakat Nasional Provinsi Jawa Barat 
melalui Bidang Amil Zakat dalam proses pengumpulan zakat maal telah menyediakan Konter Layanan Muzakki (KLM) dikantor Pengumpulan Badan Amil Zakat Nasional Provinsi Jawa Barat. Sedangkan surat elektronik, atau chatting melalui internet muzakki dapat bertanya secara pribadi melalui media tersebut perihal kendalakendala yang dihadapi dalam membayarkan zakat maal di Badan Amil Zakat Nasional Provinsi Jawa Barat. 2) Saluran komunikasi nonpribadi (Non Personal). Saluran komunikasi jenis ini melakukan proses penyampaian pesan tanpa melakukan kontak atau interaksi pribadi. Proses komunikasi ini melalui media seperti koran, majalah, website, atau acara yang dirancang sedemikian rupa untuk mengkomunikasikan produk.

Pada saluran non pribadi terjadi saat muzakki yang telah mengenal proses penyetoran zakat maal melalui Koran, majalah, website atau acara-acara sosialisasi yang telah dilakukan oleh Badan Amil Zakat Nasional Provinsi Jawa Barat selama ini, sehingga timbul keinginan dari muzakki untuk membayar zakat maal di Badan Amil Zakat Provinsi Jawa Barat.

Saluran komunikasi ini tak lepas dari peran komunikator dalam menyampaikan pesan, komunikator mempunyai peranan penting. Onong Uchjana Effendy mengartikan komunikator adalah pihak yang mengirimkan pesan kepada khalayak. Oleh karena itu , komunikator biasa disebut pengirim, sumber, soure, atau encoder.

Berdasarkan penjelasan diatas dapat dipahami sebuah tindakan aksi atau kegiatan yang dilakukan oleh seseorang atau perusahaan untuk mencapai sasaran atau tujuan yang telah di tetapkan. Sebagaimana yang telah diketahui bahwa Manajemen Komunikasi, Manajemen merupakan proses yang khas yang bertujuan untuk mencapai suatu tujuan dengan efektif dan efisien menggunakan semua sumber daya yang ada.

Strategi komunikasi merupakan paduan dari perencanaan komunikasi, dimana perencanaan merupakan fungsi dasar dari proses manajemen serta manajemen komunikasi, manajemen komunikasi disini bisa diartikan sebagai aktivitas atau fungsi dari seseorang. Mensosialisasikan dalam hal ini merupakan sebuah aktivitas komunikasi atau mengkomunikasikan sesuatu.

Proses implementasi manajemen komunikasi dalam mensosialisasikan program yang dirumuskan guna merujuk kinerja Badan Amil Zakat Nasional Provinsi Jawa Barat dalam 
mengimplementasikan program yang sudah dirumuskan dalam mengumpulkan zakat maal, diperlukan sosialisasi dan edukasi zakat kepada seluruh masyarakat secara berjenjang dan terstruktur. Penguatan BAZNAS sebagai amil lebih dioptimalkan sebagai sarana mustahik menyalurkan zakat maalnya secara efektif. Mempublikasikan setiap program pendayagunaan zakat yang tepat sasaran, baik konsumtif maupun produktif, memperkuatan kembali regulasi dan aturan tentang pengelolaan zakat yang sudah ada. Kembali malakukan sinergitas dan koordinasi dengan semua pihak.

Proses implementasi komunikasi, mensosialisasikan perubahan corporate identity diperlukan strategi, seperti yang diungkapkan oleh Onong Uchjana bahwa berhasil atau tidaknya sebuah kegiatan komunikasi secara efektif banyak ditentukan oleh strategi komunikasi.

Komunikasi ini berlangsung ketika orang-orang yang berbeda pada tataran manajemen mengirimkan pesan kepada bawahannya. Fungsi arus komunikasi dari atas ke bawah ini yaitu, pemberian atau penyampaian instruksi kerja (job instuction), penjelasan dari pimpinan tentang mengapa suatu tugas perlu dilaksanakan (job retionnale), penyampaian informasi mengenai peraturan-peraturan yang berlaku (procedure and practice), pemberian motivasi kepada karyawan untuk bekerja lebih baik.

Pentingnya komunikasi dalam perubahan sudah jelas untuk menimbulkan persesuaian paham dibenak publik, membantu orang untuk memahami mengapa perubahan dilakukan, membantu mereka melewati masa transisi, memecahkan berbagai masalah yang muncul, membuat orang terlibat dan ikut merasa bertanggungjawab, semua itu berkaitan dengan komunikasi, (Learning, 1994:70).

Berbicara tentang tujuan komunikasi persuasif tidak terlepas dari pesan orang yang melakukan persuasif (komunikator) terhadap komunikan sebagai objeknya. Seorang komunikator dikatakan berhasil dalam proses persuasif apabila komunikan melaksanakan apa yang dikehendaki dengan kesadaran sendiri tanpa merasa dipaksa oleh siapa pun.

Carl I. Hovlan dan Janis, seperti yang dikutip Onong Uchjana Effendy (2007), menyebutkan bahwa efek persuasive selalu dari asalnya, yaitu perubahan opini, perubahan persepsi, perubahan perasaan, dan perubahan tindakan. Pertama, Perubahan Opini. Efek pertama yang dapat diakibatkan oleh komunikasi persuasif adalah perubahan opini. Opini adalah evaluasi yang dinyatakan oleh verbal 
mengenai objek, orang maupun peristiwa. Kegagalan komunikan menerima isi pesan secara baik dan cermat disebut kegagalan primer ( primary breakdown in communication). Kedua, Perubahan Persepsi. Pengalaman objek tentang peristiwa atau hubungan-hubungan yang diperoleh dengan menimbulkan informasi dan menafsirkan pesan.

Ketiga, terjadinya perubahan perasaan (effect Change). Perubahan ini berkenaan dengan keadaan emosional. Perubahan ini dapat dilihat pada khalayak, misalnya kenyakan khalayak tidak dapat menerangkan dengan tegas apa yang dirasakan tetapi jika terjadi peristiwa yang mengakibatkan perubahan emosinal, maka mereka mengetahui bahwa perubahan telah terjadi. Keempat, terjadinya perubahan tindakan (action change). Tindakan adalah kumulatif dari seluruh proses komunikasi. Proses ini bukan saja memerlukan pemahaman tentang seluruh mekanisme psikologi yang terlibat dalam proses komunikasi, tetapi juga faktor-faktor fungsional maupun situasional.

Dalam konteks ini, tujuan komunikasi persuasif diharapkan dapat terjadi perubahan tindakan sebagaimana yang dikehendaki komunikator. Memang harus diakui, menimbulkan pengertian komunikan memang sullit, tetapi lebih sulit lagi mempengaruhi sikap. Jauh lebih sulit mendorong orang untuk bertindak sesuai yang diharapkan komunikator.

Persoalan komunikasi terdapat lima unsur penting yang selalu hadir, yaitu sumber informasi (source atau sender), pesan (massege atau content), penerima informasi (receiver atau audience), saluran atau media (chanel) dan pengaruh (effect).

Adapun tujuan komunikasi lewat pesan-pesan yang disampaikan dalam mensosialisasikan sesuatu terbagi menjadi empat menurut Marhaeni Fajar (Fajar, 2009), yaitu : 1) Perubahan Pendapat: dalam komunikasi berusaha menciptakan pemahaman yang dalam hal ini ialah kemampuan memaham pesan secara cermat sebagaimana dimaksudkan oleh komunikator. Setelah memahami apa yang dimaksud komunikator maka akan tercipta pendapat yang berbedabeda bagi komunikan. 2) Perubahan Sikap: seorang komunikan setelah menerima pesan kemudian sikapnya berubah, baik positif maupun negative. 3) Efek Perilaku, komunikasi bertujuan untuk mengubah peilaku maupun tindakan seseorang. 4) Perubahan Sosial, membangun dan memelihara ikatan hubungan dengan orang lain sehingga menjadi hubungan yang makin baik. 
Badan Amil Zakat Nasional Provinsi Jawa Barat menyampaikan tujuan komunikasi melalui pesan-pesan dalam sosialiasasi, tentunya menghapkan efek dari program-program yang telah dilakukan oleh Badan Amil Zakat Nasional Provinsi Jawa Barat.

Seperti telah disebutkan diatas, bahwa usaha komunikasi menimbulkan beberapa efek bagi penerimanya, mensosialisasikan perubahan ini lewat pesan yang disampaikan dan media untuk penyampaian pesan mengacu pada terciptanya efek kognitif. Efek kognitif menurut Onong Uchjana (2003:318). berhubungan dengan pikiran atau penalaran, sehingga khalayak yang semula tidak tahu, yang tadinya tidak mengerti, yang tadinya bingung, menjadi semakin jelas. Contoh pesan komunikasi melalui media massa yang menimbulkan efek kognitif antara lain: berita, tajuk rencana, artikel, acara penerangan, acara pendidikan, dan sebagainya.

Pada pengimplementasianya, formulasi manajemen komunikasi ini dilakukan saat jam kerja amil zakat. Menyalurkan dana zakat kemasyarakat sudah menjadi kewajiban bagi para amil zakat baik berupa, sembako, dana santunan kepada mustahik, pengajukan permohonan bantuan pendidikan, maupun bantuan kesehatan. Persoalan tersebut menandakan formulasi manajemen komunikasi yang diimplementasikan para amil zakat mempunyai hasil, dengan ada dua cara ini budaya kerja dan kopetensi amil yang sudah terbentuk anak mengubah persepsi dimasyarakat yang belum menzakatkan hartanya. Evaluasi secara prosedur berupa mengisi form evaluasi disetiap Rencana Kegiatan Anggatan Tahunan (RKAT) yang bersifat tahunan. Terkait dengan program-program yang sifatnya insidensial telah diatur dalam Rencana Strategis (RENSTRA) pada formulasi yang ditetapkan diawal tahunan sebelum menjalankan program kerja. persoalan tersebut dilakukan untuk meningkatkan kinerja para amil dalam mengumpulkan zakat maal di provinsi Jawa Barat. Persoalan lain dari bentuk sosialisasi yang digunakan oleh Badan Amil Zakat Nasional Provinsi Jawa Barat dalam mengumpulkan zakat maal, pada tahapan ini masih bersifat offline, yakni dengan mendatangi langsung kepada muzakki. Sosialisasi ini dilakukan secara terus-menerus sampai pada muzakki mengenal Baznas melalui Branding Zakat dengan program-program yang telah di formulasikan sedemikian rupa. Branding tersebut bekerjasama dengan lembaga lain yang ada di wilayah kerja Provinsi Jawa Barat seperti, melalui komunitas du'afa, kebencanaan, agenda sosial yang melibatkan tokoh publik. 
Bentuk sosialisasi ini dilakukan secara terus-menerus melalui mekanisme branding melalui media online maupun offline programprogram yang menjadi unggulan Badan Amil Zakat Provinsi Jawa Barat Sedangkan pengumpulan zakat maal yang bersifat online masih belum banyak dikarenakan keterbatasan sumber daya manusia untuk melakukan komunikasi melalui media tersebut. namun masyarakat masih tetap bisa mengakses informasi-informasi terkait kegiatankegiatan yang dilakukan oleh Badan Amil Zakat Nasional Provinsi Jawa Barat.

Jadi, Sosialisasi yang dilakukan Badan Amil Zakat Nasional Provinsi Jawa Barat terkait zakat maal, bersifat konsultatif. Konsultatif dalam hal ini mendengarkan keluhan muzakki, di dalam proses konsultasi ini terjadi proses komunikasi antara amil zakat dan muzakki secara prosedur pengumpulan. Kemudian dari konsultasi tersebut dapat diproses secara prosedur administrasi melalui Konter Layanan Muzakki sehingga dapat diproses oleh amil zakat kemudian setelah mendapat persetujuan dari Ketua Badan Amil Zakat Nasional Provinsi Jawa Barat. Dana pegumpulan tersebut dapat disalurkan kepada mustahik maupun masyarakat yang membutuhkan.

\section{PENUTUP}

Berdasarkan pembahasan di atas, maka dapat disimpulkan Pertama, manajemen komunikasi Badan Amil Zakat Nasional Provinsi Jawa Barat dalam mengumpulkan zakat maal, menggunakan international standart Operation (ISO), dengan proses pengumpulan zakat maal dilakukan dengan melakukan Rencana Strategis (RENSTRA) dan Rencana Kegiatan Awal Tahun (RKAT). Penerapannya dilakukan pada rapat awal tahun disetiap pergantian tahun dengan mengaplikasikan RKAT pada periode tahunannya. Sedangkan untuk periode lima tahunan lebih menggunakan RENSTRA dalam mengaplikasikan program-program Badan Amil zakat Nasional Provinsi Jawa Barat.

Kedua, Bentuk komunikasi yang digunakan oleh Badan Amil Zakat Nasional Provinsi Jawa Barat dalam Mengumpulkan Zakat Maal, menggunakan sarana media kekinian yakni media online seperti, internet, sosial media, blog, facebook, instagram dan lain-lain. Bentuk komunikasi melalui media online dilakukan secara terusmenerus diimbangi dengan bentuk komunikasi tatap muka, dengan muzakki datang langsung ke Badan Amil Zakat Nasional Provinsi 
Jawa Barat. Komunikasi selanjutnya yang dilakukan oleh Badan Amil Zaka Nasional Provinsi Jawa Barat melalui program yang langusng menyentuh masyarakat dengan Bantuan-bantuan langsung berupa sembako, biaya pendidikan untuk satu keluarga satu sarjana. Biaya usaha mandiri untuk perbaikan ekonomi masyarakat Jawa Barat. Bentuk komunikasi selanjutnya dengan cara konsultatif, konsultatif dimaksudkan dengan mendengarkan keluahan muzakki yang ingin mengeluarkan zakat maal di Badan Amil Zakat Nasional Provinsi Jawa Barat

Ketiga, sosialisasi pengumpulan zakat maal di Badan Amil Zakat Nasional Provinsi Jawa Barat dilakukan secara terus-menerus melalui program-program kerja yang dilakukan oleh Badan Amil Zakat Nasional Provinsi Jawa Barat. melalui mekanisme branding melalui media online yang dikemas sedemikian rupa yang dilakukan secara konsisten walaupun melalui media ini masih belum optimal. Akan tetapi sosialisasi yang optimal dilakukan pada saat ini dengan menggunakan offline dengan langsung bertatap muka dengan muzakki.

Badan Amil Zakat Nasional Provinsi Jawa Barat dalam mengumpulkan zakat maal masih dalam tahapan membangun system komunikasi secara umum kepada masyarakat Jawa Barat. Persoalan ini dikarenakan masih banyaknya masyarakat yang telah mencapai nishab dalam perhitungan zakat maal belum menzakatkan sebagian hartanya. Persoalan ini disebabkan kurangnya pengetahuna dan kesadaran pada masyarakt Provinsi Jawa Barat dalam mengeluarkan zakat yang telah mencapai nishab. Hasil penelitian ini secara keilmuan bagi pengembangan dakwah dapat menambah khazanah keilmuan dalam ilmu komunikasi dan penyiaran Islam. Hasil penelitian ini juga bisa dijadikan refleksi dan model pendekatan dakwah dan pemberdayaan masyarakat melalui Badan Amil Zakat. Selanjutnya untuk penelitian lanjutan dapat diarahkan pada perkembangan zakat melalui Online baik dalam segi metodologi, teori dan pembahasan lainnya yang masih luas untuk dikaji.

\section{DAFTAR PUSTAKA}

Bandung, P. (2016). Pemkot Bandung Luncurkan Gerakan Ayo Bayar Zakat. Diambil dari https:// portal.bandung.go.id/ posts/2016/05/30/vqvD/ pemkotbandung-luncurkan-gerakan-ayo-bayar-zakat

Baznas. (2014). Peraturan Badan Amil Zakat Nasional Nomor 03 Tahun 
2014, tentang Tugas, Kedudukan, Dan Fungsi. Jakarta: Baznas.

Baznas. (2016). Data: Arsip Badan Amil Zakat Provinsi Jawa Barat. Bandung: Baznas Provinsi Jawa Barat.

David, F. R. (2006). Manajemen strategis. (terj.) Ichsan Setiyo Budi Edisi Kesepuluh. Jakarta: Penerbit Salemba Empat.

Effendy, O. U. (2007). Ilmu Komunikasi Teori dan Praktek. Bandung.

Fajar, M. (2009). IImu Komunikasi . YTogyakalkta: Praktik Graha Ilmu.

George, B., \& Michael, G. (2007). Adversiting and Promotion: An Integrated Marketing Communication Perspektive. New York: McGraw Hill.

Hasanah, U. (2005). Efektifitas Distribusi Zakat Baznas Sumsel Dalam Meningkatkan Kesejahteraan Mustahik Di Pasar Kuto Periode 2011-2013. IN Raden Fatah Palembang.

Learning, M. O. (1994). Merencanakan Dan Mengelola Perubahan (Planning And Managing Change)-Edisi Bahasa Indonesia. Jakarta: PT Gramedia Pustaka Utama.

Mulyana, D. (2007). Ilmu Komunikasi: Suatu Pengantar. Bandung: Remaja Rosdakarya.

Rahmayati, R. S. (2013). Manajemen Pendistribusian Zakat Studi deskriptif di Rumah Zakat Turangga No 25 C Bandung. UIN Sunan Gunung Djati Bandung.

Syafaruddin. (2005). Manajemen Lembaga Pendidikan Islam, Cet.1. Jakarta: Ciputat Press.

Yaser, M. E1. (2016). Upaya Komunikasi Persuasif Berzakat Ke Badan Amil Zakat Nasional (Baznas) Di Kota Padang. diakses. Skripsi. Diambil 8 Januari 2017, dari http://scholar.unand.ac.id/17900/ 